\title{
Serial concentrations of C-reactive protein as an indicator of urinary tract infection in patients with spinal injury
}

\author{
A GALLOWAY, HT GREEN, JJ WINDSOR, KK MENON,* BP GARDNER,* \\ KR KRISHNAN*
}

From the Department of Bacteriology, Southport General Infirmary, and the * Regional Spinal Injuries Centre, Southport Promenade Hospital, Merseyside

SUMMARY C-reactive protein (CRP) was measured serially in 16 patients with an acute spinal injury. Twelve episodes of acute urinary tract infection (UTI) occurred during the study period. These were all associated with an increased concentration of CRP $>50 \mathrm{mg} / \mathrm{l}$, which returned to normal after successful treatment. Thirteen episodes of asymptomatic bacteriuria associated with increased concentrations of CRP $>20 \mathrm{mg} / 1$ occurred, indicating tissue damage. More commonly, significant bacteriuria was associated with normal concentrations of CRP, and presumably, simple colonisation of the urinary tract, which, we suggest, does not require treatment with antibiotics. Serial measurement of CRP in patients with spinal injury may help distinguish between urinary tract colonisation and infection and be useful in monitoring the response to the treatment of clinical UTI.

Urinary tract infections (UTI) are a major cause of morbidity in patients with spinal injury. ${ }^{1}$ Such patients commonly have bacteriuria, but it is difficult to assess the clinical importance of this as the usual clinical signs of cystitis or pyelonephritis may be absent. Various methods have been used to try to localise the site of the infection in the urinary tract. These have included catheterisation with quantitative bacterial counts using the bladder washout technique of Fairley $e t \mathrm{al}^{2}$ and ureteric catheterisation to determine if unilateral or bilateral upper UTI is present. There is a need, however, for a reliable and convenient test for identifying invasive urinary tract infection. Serial concentrations of CRP have been advocated for the monitoring of disease processes in connective tissue disease, ${ }^{3}$ infections in leukaemic patients, ${ }^{4-7}$ and childhood infections, ${ }^{8}$ and for the diagnosis of acute infections such as appendicitis, ${ }^{9}$ meningitis, ${ }^{10}$ and pyelonephritis. ${ }^{11-14}$ Studies of the use of CRP for the diagnosis of UTI have so far been confined to the study of schoolgirls ${ }^{11-14}$ and patients with ileal conduits. ${ }^{15}$

We studied prospectively serial CRP concentrations in 16 patients newly admitted to a regional spinal injuries unit and the relation to the presence of

Accepted for publication 13 March 1986 bacteriuria, clinical evidence of infection, and response to treatment to determine the value of such estimations as a guide to invasive infection.

\section{Patients and methods}

Sixteen patients admitted between September 1982 and May 1983 with an acute spinal injury were studied. All had been previously healthy and were not suffering from any known malignancy or connective tissue disease. They comprised 13 men and three women aged 12-68 years (mean 40 years). Twelve were suffering from paraplegia, four were tetraplegic. Thirteen patients required catheter drainage, at least initially, two male patients were managed with condom drainage, and one patient with mild paraplegia had normal bladder function.

\section{INVESTIGATIONS}

$C$-reactive protein

Serum CRP was measured twice weekly for up to 169 days after injury using single radial immunodiffusion with low concentration Partigen plates and standardised using a commercially available CRP standard serum (Hoechst Pharmaceuticals). The standard was used neat and diluted $1 / 2$ and $1 / 4$ in distilled water. Plates were incubated for 48 hours at room tem- 
perature, and the value of CRP was determined from a linear calibration curve (assay range $0-100 \mathrm{mg} / \mathrm{l}$ ). Additional samples were obtained when a urinary tract infection was suspected and after treatment for UTI, an average of 17 estimations per patient. Measurement of CRP was performed on control samples of serum obtained from 16 healthy age and sex matched volunteers. CRP was related to:

1 Clinical evidence of infection as indicated by routine clinical examination; rigors or fever, defined as a rise in temperature to more than $38^{\circ} \mathrm{C}$ for more than two hours, or a rise in temperature of $1^{\circ} \mathrm{C}$ or more above the baseline temperature for more than two hours if defective thermoregulation was present; positive blood cultures, or a peripheral leucocytosis of more than $10 \times 10^{9} / 1$.

2 Presence of significant bacteriuria (defined as $>10^{3}$ organisms $/ \mathrm{ml}$ from a catheter specimen of urine or $>10^{5} / \mathrm{ml}$ from a mid stream urine).

3 Clinical recovery following treatment for UTI and return of temperature and white cell count to normal.

\section{ADDITIONAL INVESTIGATIONS}

Daily clinical records were kept of any symptoms or signs of infection in the urinary tract or at other sites; fever; treatment with antibiotics or urinary antiseptics; and the type of urinary drainage system used. Routine samples of urine for culture and serum for CRP were examined twice weekly. If a patient became feverish or had clinical evidence of septicaemia blood cultures were performed, CRP concentrations measured, and urine cultured. After treatment for UTI CRP was measured once more and urine cultured. Raised CRP values in the presence of sepsis other than UTI were excluded from the analysis.

Renal function was monitored biochemically and radiologically. Serum urea and creatinine were estimated twice weekly, and intravenous pyelograms were performed, where possible, two to three months after the acute injury and annually.

\section{Results}

Patients were studied for an average of 93 days (21-169 days), and 266 serum samples were assayed. On admission 13 patients had raised values of CRP. Eleven patients developed significant bacteriuria during the study and three patients were bacteriuric on admission. Bacteriuria appeared by the tenth day of admission in those not receiving antibiotics but was present in all 14 patients by the end of the third week of admission.

In all but one patient CRP values fell to normal

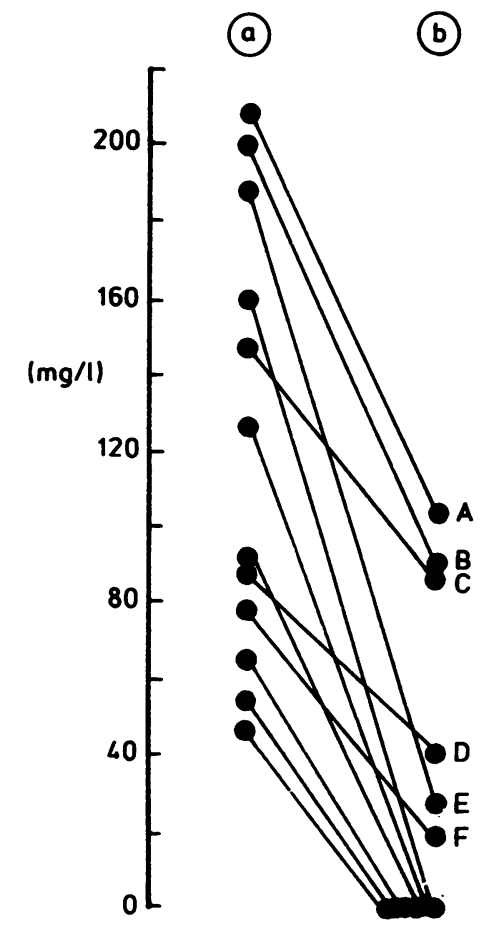

Fig 1 Fall in CRP concentration ( $\mathrm{mg} / \mathrm{l})$ with antimicrobial treatment in 12 episodes of acute UTI: (a) peak value of $C R P$ during $U T I(b) C R P$ value seven days after starting treatment.

( $<10 \mathrm{mg} / \mathrm{l})$ between 11 and 58 days after injury. In patients with extensive trauma or infective complications after injury the fall in CRP to normal was delayed. One patient with tetraplegia who required ventilation developed chronic chest problems and CRP values did not at any time fall in the normal range.

SYMPTOMATIC BACTERIURIA

During the study period 12 episodes of clinically apparent UTI developed in six patients. In all 12 episodes CRP values were raised: range $50-210 \mathrm{mg} / 1$ mean $121 \mathrm{mg} / \mathrm{l})$. Symptoms ranged from non-specific malaise with mild fever to those of clinical pyelonephritis with rigors and vomiting. On five of these occasions rising concentrations of CRP were detected before clinical infection was evident.

Treatment was associated with an appreciable fall in CRP. Fig. 1 shows the peak values of CRP during an acute episode of UTI and a fall of CRP with treatment. In six cases CRP values had not fallen to normal within one week. On four of these occasions (B, D, E, F) the initial antibiotic treatment had not 


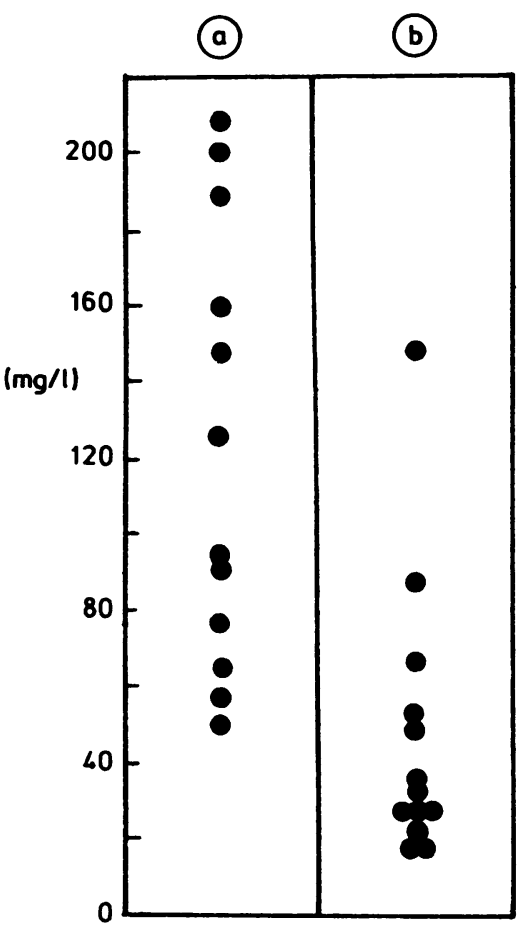

Fig 2 Peak values of CRP ( $m g / l)$ in patients with (a) symptomatic bacteriuria, (b) asymptomatic bacteriuria and raised values of CRP.

been appropriate (urinary isolate resistant to the antibiotic prescribed). A change to appropriate antibiotics was associated with a fall of CRP to normal after 14 days. On one occasion (C) the initial treatment was appropriate but the infecting organism was quickly replaced by a resistant strain of Pseudomonas aeruginosa, and CRP values showed a further rise in titre after 14 days. On another occasion (A) the patient had clinical pyelonephritis due to Pseudomonas aeruginosa but had received only one antibiotic (netilmicin) for this infection. The isolate seemed to be sensitive to netilmicin on routine testing, but CRP values failed to fall to normal and later rose to $152 \mathrm{mg} / \mathrm{l}$ when the patient no longer had clinical signs of pyelonephritis but had significant bacteriuria and pyuria.

\section{ASYMPTOMATIC BACTERIURIA}

On 95 occasions a CRP value of $<10 \mathrm{mg} / \mathrm{l}$ was detected when significant bacteriuria was present. There was no clinical evidence of infection, although pyuria was found in 25 samples. Two patients, who were studied for 56 and 169 days, respectively and who were catheterised during this period and had almost persistent bacteriuria, did not at any time have values of CRP $>12 \mathrm{mg} / \mathrm{l}$, nor did they have any signs or symptoms of UTI. They did not receive antibiotics.

On 13 occasions peak values of CRP $>20 \mathrm{mg} / 1$ were detected in six patients (Fig. 2) when they were clinically well and the only known site of infection or inflammation was the urinary tract. They did not receive treatment with antibiotics and in most cases CRP values had fallen to normal within one week. On four occasions normal values were detected only after fourteen days.

Values of CRP $<10 \mathrm{mg} / 1$ were detected in 16 age and sex matched healthy controls.

\section{RENAL FUNCTION}

All patients were followed up for at least 18 months after the acute injury had been sustained. During that period two elderly patients (66 and 68 years) with tetraplegia died from respiratory complications. No patient developed renal failure; two of the six patients, however, who had asymptomatic bacteriuria associated with increased values of CRP and who did not receive antibiotics for these episodes, had evidence of bladder abnormalities on intravenous pyelograms (trabeculated bladder with diverticular formation). No patient who had consistent asymptomatic bacteriuria and normal values of CRP developed evidence of renal failure or abnormalities on intravenous pyelograms. Prolonged follow up studies of renal function, however, will be necessary to establish if there are any important differences between these groups.

\section{Discussion}

Management of UTI in patients with neurogenic bladders poses special problems, and infection within the urinary tract is a major cause of morbidity in patients with spinal injuries. ${ }^{1}$ Renal failure associated with chronic pyelonephritis, hypertension, and amyloidosis was found to be the commonest cause of death in patients with paraplegia surviving acute injury. ${ }^{16}$ Patients suffering traumatic paraplegia are likely to require long term catheterisation or urinary appliances, and bacteriuria rapidly develops in these patients. ${ }^{17}$ Disturbances of sensation and thermoregulation may mask the classical signs of cystitis and pyelonephritis. It may be difficult to decide which patients require treatment with antibiotics as these patients commonly have bacteriuria, and not all patients with bacteriuria need to be treated. Indeed, the inappropriate use of antibiotics is associated with: the emergence of resistant organisms, which are subsequently difficult to eradicate; risk to the patient of unwanted side effects of antibiotics; unnecessary expense; and risk to other patients from cross infection with resistant organisms. 
CRP (as an acute phase reactant) was first described in $1930^{18}$; it was subsequently used to detect non-infectious inflammatory conditions as well as infectious conditions. Interest, however, declined as the classical immunoprecipitation method for measuring values could not provide a rapid result. In 1979 Mackie $e t a l^{4}$ studied the use of CRP as a means of rapid diagnosis of infection in patients with leukaemia. In these patients infection may be difficult to diagnose as clinical signs of infection may be masked by neutropenia and the disease process itself may cause a rise in body temperature. Other workers confirmed the usefulness of this assay in detecting acute infection in leukaemia ${ }^{57}$ and in monitoring the response to treatment with antibiotics. ${ }^{6}$ Jodal et al in $1975^{11}$ studied schoolgirls with symptomatic bacteriuria and correlated the clinical diagnosis of pyelonephritis or cystitis with the bladder washout test, serum antibody values, sedimentation rate, CRP, and renal concentrating ability. Highest reliability from a single test in distinguishing between pyelonephritis and cystitis was obtained by CRP determinations followed by antibody titration, sedimentation rate, and renal concentrating ability. Increased CRP values (range $25-300 \mathrm{mg} / \mathrm{l}$ ) were found in all patients classified as having pyelonephritis. In a further study on schoolgirls with asymptomatic bacteriuria ${ }^{12}$ there was a poor correlation between "high infection" indicated by the bladder washout test and abnormal values of CRP, sedimentation rate, antibody titres, or renal concentrating ability. In most of the patients with a "high infection" according to the bladder washout test, however, it was impossible to decide if bacteriuria was of renal origin or if bladder urine retained in the refluxing ureters was emptying into the bladder after washing, giving values indicative of renal infection.

Jodal and Hanson ${ }^{13}$ subsequently studied the usefulness of sequential determinations of CRP values in acute childhood pyelonephritis. They found that treatment with antibacterial drugs to which the bacteria were fully sensitive resulted in a rapid decrease of the CRP values, and very low or trace amounts were attained within a week. Patients ineffectively treated or reinfected showed increasing or slowly decreasing CRP values. Our results from patients with spinal injury also indicate that serial measurements of CRP would be useful in indicating a successful response to treatment for those with symptomatic UTI.

In 1982 Hellerstein et $\boldsymbol{l}^{14}$ did not find that serum CRP concentrations were accurate in localising the site of UTI in girls who did not have clinical signs of acute pyelonephritis. They used the bladder washout test as a reference method for determining the site of UTI and they assumed that serum CRP concentrations $>30 \mu \mathrm{g} / \mathrm{ml}$ were indicative of tissue inflammation - that is, pyelonephritis. They found that the predictive value of a positive laboratory test for CRP in patients with pyelonephritis was $57 \%$. The predictive value for a negative test, however, was $83 \%$. There is at present no appropriate convenient reference method for the localisation of the site of urinary tract infections. Most workers use the bladder washout test, but, the constant outflow of bacteria into the renal pelvis is required if counting of bacteria in ureteric or bladder urine is to be used as an indicator of kidney infection, and this does not always occur. Clinical signs of pyelonephritis are notoriously unreliable for the level of diagnosis of urinary tract infection.

Kiker et $\mathrm{l}^{15}$ studied the usefulness of serum CRP as a means of localising the site of urinary tract infection in patients with ileal conduits. As many as $85 \%$ of patients with conduits have been reported to have positive urine cultures, but it is unclear whether this represents chronic asymptomatic pyelonephritis or simple colonisation of the conduit. They studied 19 patients, none of whom had clinical symptoms of pyelonephritis but 10 of whom had significant bacteriuria. All patients had CRP values $>18 \mathrm{mg} / \mathrm{l}$, regardless of the urine culture. They therefore concluded that CRP was of no value in distinguishing renal bacteriuria from conduit colonisation.

We assessed the value of serial CRP concentrations in patients with spinal injury as invasive urinary tract infection can be difficult to diagnose in this group. Our study confirmed that in these patients with clinical UTI increased values of CRP $>50 \mathrm{mg} / \mathrm{l}$ are found, although more sampling of serum might have shown higher peak values. Successful treatment of UTI was associated with a fall in CRP to normal. Increased values of CRP were also shown in patients who did not have clinical UTI or other sites of sepsis but who were bacteriuric - presumably, the cause of this raised CRP concentration was inflammation within the urinary tract. An increased concentration of CRP is unequivocal evidence of an active tissue damaging process, ${ }^{3}$ but values can only be interpreted in the light of full clinical information. We suggest that an increased value of CRP in the presence of bacteriuria and the absence of other known sites of sepsis or inflammation indicates an invasive urinary tract infection, and as such requires treatment with antibiotics. Conversely, a normal value of CRP in the presence of bacteriuria indicates simple bladder colonisation and does not require antibiotics. Serial monitoring of CRP may therefore be helpful in distinguishing infection from colonisation and in monitoring the response of UTI to treatment. Rapid methods for CRP estimation, however, would need to be used (laser nephelometry, enzyme immunoassay), to aid clinical management. We are at present evalu- 
ating the use of the antibody coated bacteria test in conjunction with CRP values as a guide to the level of diagnosis of UTI in patients with spinal injury.

The work was supported by a grant from the Regional Research Committee, Mersey Regional Health Authority.

\section{References}

${ }^{1}$ Merritt JL. Urinary tract infections, causes and management with particular reference to the patient with spinal cord injury: a review. Archives of Physical Medicine and Rehabilitation 1976;57:365-73.

${ }^{2}$ Fairley KF, Carson NE, Gutch RC, et al. Site of infection in acute urinary tract infections in general practice. Lancet 1971;ii: 615-18.

${ }^{3}$ Pepys MB. C-reactive protein fifty years on. Lancet 1981;i:653-7.

4 Mackie PH, Crockson RA, Stuart J. C-reactive protein for rapid diagnosis of infection in leukaemia. J Clin Pathol 1979;32: 1253-6.

${ }^{5}$ Rose PE, Johnson SA, Meakin M, Mackie PH, Stuart J. Serial study of C-reactive protein during infection in leukaemia. J Clin Pathol 1981;34:263-6.

${ }^{6}$ Schofield KP, Voulgari F, Gozzard DI, Leyland MJ, Beeching NJ, Stuart J. C-reactive protein concentration as a guide to antibiotic therapy in acute leukaemia. J Clin Pathol 1982;35:866-9.

${ }^{7}$ Williams M, McCallum J, Dick HM. The detection of infection in leukaemia by serial measurement of $\mathrm{C}$-reactive protein. $\boldsymbol{J}$ Infect 1982;4:139-47.

${ }^{8}$ Peltola H, Rasanen JA. Quantitative C-reactive protein in relation to erythrocyte sedimentation rate, fever and duration of antimicrobial therapy in bacteraemic diseases of childhood. $J$ Infect
1982;5:257-67.

${ }^{9}$ Marchand A, Van Lente F, Galen RS. The assessment of laboratory tests in the diagnosis of acute appendicitis. Am J Clin Pathol 1983;80:369-74.

${ }^{10}$ Peltola H. C-reactive protein for rapid monitoring of infections of the central nervous system. Lancet 1982;i:980-3.

11 Jodal U, Lindberg U, Lincoln $\mathrm{K}$. Level diagnosis of symptomatic urinary tract infection in childhood. Acta Paediatr Scand 1975;64:201-8.

${ }^{12}$ Lindberg U, Jodal U, Hanson LA, Kaijser B. Asymptomatic bacteriuria in schoolgirls. IV. Difficulties of level diagnosis and the possible relation to the character of infecting bacteria. Acta Paediatr Scand 1975;64:574-80.

${ }^{13}$ Jodal U, Hanson LA. Sequential determination of C-reactive protein in acute childhood pyelonephritis. Acta Paediatr Scand 1976;65:319-22.

${ }^{14}$ Hellerstein S, Duggan E, Welchert E, Mansour F. Serum $C$-reactive protein and the site of urinary tract infection. J Pediatr 1982;100:21-5.

${ }^{15}$ Kiker JD, Woodside JR, Reed WP, Borden TA, Woodside MD. Urinary lactic dehydrogenase and serum $\mathrm{C}$-reactive protein as means of localizing the site of urinary tract infection in patients with ileal conduits. J Urol 1982;128:749-51.

${ }^{16}$ Tribe CR. Causes of death in the early and late stages of paraplegia. Paraplegia 1963;1:19-46.

${ }^{17}$ Clayton CL, Chawla JC, Stickler DJ. Some observations on urinary tract infections in patients undergoing long-term bladder catheterization. J Hosp Infect 1982;3:39-47.

${ }^{18}$ Tillett WS, Francis T. Serological reactions in pneumonia with a non-protein somatic fraction of pneumococcus. $J \operatorname{Exp} M e d$ 1930;52:561-71.

Requests for reprints to: Dr A Galloway, Department of Medical Microbiology, Whiston Hospital, Warrington Road, Whiston, Merseyside L35 SDR, England. 